\title{
Simultaneous Detection of Listeria monocytogenes, Escherichia coli 0157:H7, Bacillus cereus, Salmonella spp., and Staphylococcus aureus in Low-fatted Milk by Multiplex PCR
}

\author{
Ji-Hyun Kim¹, Seong-Ryul Rhim¹, Kee-Tae Kim², Hyun-Dong Paik ${ }^{1}$, and Joo-Yeon Lee* \\ Korea Livestock Products HACCP Accreditation Service, Anyang 430-731, Korea \\ ${ }^{1}$ Department of Food Science and Biotechnology of Animal Resources, Konkuk University, Seoul 143-701, Korea \\ ${ }^{2}$ Bio/Molecular Informatics Center, Konkuk University, Seoul 143-701, Korea
}

\begin{abstract}
A rapid and specific PCR assay for the simultaneous detection of Listeria monocytogenes, Escherichia coli O157:H7, Bacillus cereus, Salmonella spp., and Staphylococcus aureus in foods was developed to reduce the detection time and to increase sensitivity. Multiplex PCR developed in this study produced only actA, fliC, hbl, invA, ileS amplicons, but did not produce any non-specific amplicon. The primer sets successfully amplified the target genes in the multiplex PCR without any non-specific or additional bands on the other strains. The multiplex PCR assays also amplified some target genes from five pathogens, and multiplex amplification was obtained from as little as $1 \mathrm{pg}$ of DNA. According to the results from the sensitivity evaluation, the multiplex PCR developed in this study detected 10 cells $/ \mathrm{mL}$ of the pathogens inoculated in milk samples, respectively. The results suggested that multiplex PCR was an effective assay demonstrating high specificity for the simultaneous detection of five target pathogens in food system.
\end{abstract}

Keywords: simultaneous detection, multiplex PCR, pathogens, low-fatted milk

\section{Introduction}

In these days, the microbial safety of food is getting significant concern in consumers and food industry. Food microbial contamination is not often discovered by individual hygiene and hygiene reinforcement in food production steps. However, there is still a risk of microbial contamination of food throughout the processing before consumption. The rapid and accurate identification of bacterial pathogens in food is important and have been studied by many researchers, both for quality assurance and trace of bacterial pathogens within the food supply (Bhagwat, 2003; Settanni and Corsetti, 2007; Yang et al., 2013a). Current methods for the detection of food-borne pathogens generally involve the following: (a) colony isolation on selective media, (b) the use of biochemical tests, and (c) serotyping using antibodies against specific bacterial antigens. However, these traditional culture-based me-

\footnotetext{
*Corresponding author: Joo-Yeon Lee, Korea Livestock Products HACCP Accreditation Service, Anyang 430-731, Korea. Tel: +82-31-390-5275; Fax: +82-31-465-6698, E-mail: ljy@ihaccp. or.kr
}

thods are both cumbersome and time consuming (Kim et al., 2010). Recently, a polymerase chain reaction (PCR) method has been developed and applied frequently for detection of pathogenic microorganisms due to its rapidity and more feasibility for industrial application. There has been a lot of discussion about using multiplex PCR assay for the detection of pathogenic microorganisms in previous studies (Abd-Elmagid et al., 2013; Mukhopadhyay and Mukhopadhyay, 2007; Omiccioli et al., 2009).

Bacillus cereus and Staphylococcus aureus are grampositive, spore-forming bacteria. Due to their spore-forming ability, they can pose problems in the food industry. In addition to this, Staphylococcus aureus food poisoning resembles Bacillus cereus food-borne intoxication in its symptoms and incubation period (Abd-Elmagid et al., 2013; Cremonesi et al., 2005; Kumar et al., 2009; Stenfors Amesen et al., 2007). Escherichia coli O157:H7, Listeria monocytogenes, and Salmonella spp. are dangerous food-borne pathogens and important pathogens spreading through various foods, afflicting human health worldwide (Amagliani et al., 2004; Yuan et al., 2009).

Milk has been known to have high nutritional value and be contaminated easily with microorganisms. In particu- 
lar, dairy products contaminated with pathogens can be fatal to babies, immunocompromised patients, and pregnant women. Therefore, new approaches in safety of dairy products are needed to find fast and efficient detection technique with high detection sensitivity in the area of milk and milk products.
The direct detection of pathogenic bacteria in food samples is hampered by the presence of PCR-inhibitory substances frequently associated with enrichment media, DNA isolation reagents, and the food matrix itself (Oikarinen et al., 2009). In the present study, a species-specific primer set that can selectively amplify regions of geno-

Table 1. List of pathogen and non-pathogen bacterial strains used for specificity tests

\begin{tabular}{|c|c|c|c|}
\hline Type & No. & Strain & Source \\
\hline \multirow{25}{*}{ Pathogen } & 1 & Bacillus cereus & Lab collection \\
\hline & 2 & Bacillus cereus & KCCM 11341 \\
\hline & 3 & Bacillus cereus & KCCM 40935 \\
\hline & 4 & Escherichia coli $\mathrm{O} 157: \mathrm{H7}$ & Lab collection \\
\hline & 5 & Escherichia coli $\mathrm{O} 157: \mathrm{H7}$ & ATCC 43894 \\
\hline & 6 & Escherichia coli $\mathrm{O} 157: \mathrm{H} 7$ & ATCC 43895 \\
\hline & 7 & Escherichia coli O157:H7 FRIK125 & From ISU ${ }^{\mathrm{a}}$ \\
\hline & 8 & Escherichia coli O157:H7 93-062 & From ISU ${ }^{\mathrm{a}}$ \\
\hline & 9 & Staphylococcus aureus & КССМ 32395 \\
\hline & 10 & Staphylococcus aureus & ATCC 25923 \\
\hline & 11 & Staphylococcus aureus & KCCM 40510 \\
\hline & 12 & Salmonella Enteritidis & KCCM 12021 \\
\hline & 13 & Salmonella Typhimurium & ATCC 14802 \\
\hline & 14 & Salmonella Gallinarum & ATCC 9184 \\
\hline & 15 & Salmonella Enteritidis & ATCC 13076 \\
\hline & 16 & Salmonella Typhimurium & Lab collection \\
\hline & 17 & Salmonella st. paul & From ISU ${ }^{\mathrm{a}}$ \\
\hline & 18 & Salmonella Gaminara 8324 & From ISU ${ }^{\mathrm{a}}$ \\
\hline & 19 & Salmonella Oranienbury 9329 & From ISU ${ }^{\mathrm{a}}$ \\
\hline & 20 & Listeria monocytogenes & ATCC 15313 \\
\hline & 21 & Listeria monocytogenes ScottA & From ISU ${ }^{\mathrm{a}}$ \\
\hline & 22 & Listeria monocytogenes H7969 & From ISU ${ }^{\mathrm{a}}$ \\
\hline & 23 & Listeria monocytogenes $\mathrm{H} 7962$ & From ISU ${ }^{\mathrm{a}}$ \\
\hline & 24 & Listeria monocytogenes $\mathrm{H} 7596$ & From ISU ${ }^{\mathrm{a}}$ \\
\hline & 25 & Listeria monocytogenes H7762 & From ISU ${ }^{\mathrm{a}}$ \\
\hline \multirow{20}{*}{ Non-pathogen } & 26 & Bacillus subtilis & IFO 12113 \\
\hline & 27 & Bacillus subtilis BR40 & Lab collection \\
\hline & 28 & Bacillus thuringiensis & Lab collection \\
\hline & 29 & Bacillus spp. MY2 & Lab collection \\
\hline & 30 & Bacillus amyloliquefaciens KU801 & Lab collection \\
\hline & 31 & Escherichia coli & KCСM 32396 \\
\hline & 32 & Escherichia coli & ATCC 25922 \\
\hline & 33 & Escherichia coli (-) control & Lab collection \\
\hline & 34 & Escherichia coli & ATCC 10536 \\
\hline & 35 & Escherichia coli DH5a & Lab collection \\
\hline & 36 & Staphylococcus epidermidis & ATCC 12228 \\
\hline & 37 & Staphylococcus chromogenes 19 & Lab collection \\
\hline & 38 & Staphylococcus xylosus 29 & Lab collection \\
\hline & 39 & Staphylococcus hylococcus 54 & Lab collection \\
\hline & 40 & Staphylococcus simulans 78 & Lab collection \\
\hline & 41 & Listeria grayi & КCTC 3443 \\
\hline & 42 & Listeria ivanovii subsp. ivanovii & КСТС 3444 \\
\hline & 43 & Listeria grayi & KCTC 3581 \\
\hline & 44 & Listeria welshimeri & KCTC 3587 \\
\hline & 45 & Listeria seeligeri & КСТС 3591 \\
\hline
\end{tabular}

${ }^{\mathrm{a}}$ From Aubrey F. Mendonca, Department of Food Science and Human Nutrition, Iowa State University, Ames, IA 
mic DNA in simplex and multiplex PCR reactions was designed. The PCR assay was validated by species specific amplification of known amount of DNA with same set of primers.

The major focus of this study was to investigate the specificity of a multiplex PCR designed for the simultaneous detection of five major foodborne pathogens to be found in milk (Listeria monocytogenes, Escherichia coli 0157:H7, Bacillus cereus, Staphylococcus aureus, and Salmonella spp.) and its sensitivity by measuring the detection limit of bacterial cell cultures as a single pathogen in milk.

\section{Materials and Methods}

\section{Bacterial strains and culture conditions}

A total of 45 pathogenic and non-pathogenic bacterial strains were used in this study as listed in Table 1. The cultures were maintained on Tryptic Soy Agar (TSA; Difco Laboratories, USA). The plates were incubated at $37^{\circ} \mathrm{C}$ for $18-24 \mathrm{~h}$ in order to allow the microbial growth. A single colony was selected and grown overnight at $37^{\circ} \mathrm{C}$ in Tryptic Soy Broth (TSB; Difco Laboratories, USA).

\section{Genomic DNA extraction}

Three different methods for genomic DNA extraction from pure culture were used. Bacteria grown overnight in TSB were centrifuged at $8,900 \mathrm{~g}$ for $15 \mathrm{~min}$. The pelleted cells were then used for DNA extraction. The cells were re-suspended in $100 \mu \mathrm{L}$ of Tris-EDTA (TE) buffer and boiled for $10 \mathrm{~min}$. After cooling on ice for $15 \mathrm{~min}$, the collected cells were centrifuged at $16,600 \mathrm{~g}$ for $1 \mathrm{~min}$. Finally, the supernatant was used for the PCR (Germini et al., 2009).

Pure genomic DNA was extracted with an AccuPrep ${ }^{\circledR}$ genomic DNA extraction kit (Bioneer Co., Korea) in accordance with the manufacturer's direction, along with lysozyme (Sigma Chemical Co., USA).

The isolation of bacterial genomic DNA was performed with some modifications of the method described (Neumann et al., 1992; Pospiech and Neumann, 1995). The pellet was re-suspended in $5 \mathrm{~mL}$ of SET buffer $(50 \mathrm{mM}$ $\mathrm{NaCl}, 25 \mathrm{mM}$ EDTA, $20 \mathrm{mM}$ Tris-Cl, pH 7.5) containing $10 \mathrm{mg} / \mathrm{mL}$ of lysozyme. After an incubation for $1 \mathrm{~h}$ at $37^{\circ} \mathrm{C}, 2.5 \mathrm{~mL}$ of $0.5 \mathrm{M}$ EDTA was added, and incubated for $5 \mathrm{~min}$ at room temperature. Then, $4 \mathrm{~mL}$ of $10 \%(\mathrm{~m} / \mathrm{v})$ SDS and proteinase $\mathrm{K}$ was added to a final concentration of $1 \mathrm{mg} / \mathrm{mL}$, and incubated at $65^{\circ} \mathrm{C}$ for $30 \mathrm{~min}$. Equal volume of phenol:chloroform:isoamylalcohole (25:24:1, PCI) were added, and gently mixed. The mixture was centrifuged at $8,900 \mathrm{~g}$ for $15 \mathrm{~min}$, the upper aqueous phase was transferred to a new tube, and RNase A was added to a final concentration of $20 \mu \mathrm{g} / \mathrm{mL}$, and incubated at $37^{\circ} \mathrm{C}$ for $1 \mathrm{~h}$. The solution was extracted with an equal volume of PCI. Then, $5 \mathrm{M} \mathrm{NaCl}$ added to final concentration of $0.1 \mathrm{M}$ and two volumes of absolute ethanol were added and gently mixed. The DNA was spooled out, washed with $70 \%$ ethanol, dried, and dissolved in a suitable volume of TE buffer ( $\mathrm{pH}$ 8.0).

The concentration of DNA was estimated by $\mathrm{A}_{260}$, and the quality and purity of DNA was evaluated by $\mathrm{A}_{260} / \mathrm{A}_{280}$ and electrophoretic analysis.

\section{Primer design}

All the primers used for this study were chosen for biomarker and were designed indigenously by using the Gen Bank database (Table 2). The design and theoretical analysis of primers with respect to self-complementarity, interprimer annealing, and optimum annealing temperatures were accomplished by means of the FastPCR software program (http://primerdigital.com/fastpcr.html). Primers were tested for PCR amplification at five different annealing temperatures.

Table 2. Primers designed for the multiplex PCR

\begin{tabular}{|c|c|c|c|c|}
\hline Microorganism & Acc. number & Primer sequence $\left(5^{\prime}-3^{\prime}\right)$ & Target gene & Amplicons (bp) \\
\hline L. monocytogenes & AE017262 & $\begin{array}{l}\text { TAGTTCGCTGAATAGTGGCGA } \\
T \text { TGCTTTTTCGTCTTCTGCAC }\end{array}$ & act $A$ & 611 \\
\hline E. coli $\mathrm{O} 157: \mathrm{H} 7$ & AE005174 & $\begin{array}{c}\text { ACATCTTTACTCACTGTAGCCTG } \\
\text { AACTACCGATGCTGCATTCGA }\end{array}$ & $f l i C$ & 519 \\
\hline B. cereus & AE016877 & $\begin{array}{c}\text { TCATTGATTTGCCGTTGCGTAT } \\
\text { GTCACATCCATTGTAACTGGAGGA }\end{array}$ & $h b l$ & 437 \\
\hline Salmonella spp. & AM933172 & $\begin{array}{c}\text { TTCTCTTGGCGCCCACAATGCGAG } \\
\text { TCCATCAGCAAGGTAGCAGTC }\end{array}$ & $\operatorname{invA}$ & 338 \\
\hline S. aureus & NC_003923.1 & $\begin{array}{c}\text { CATACAGCACCAGGTCACGGGGAA } \\
\text { GTTCTCCAGTCGTGTGGATAGC }\end{array}$ & iles & 227 \\
\hline
\end{tabular}




\section{Specificity and detection limit assays}

The specificity of the PCR assay was tested by using, as a template, the extracted DNA by a boiling method of bacteria listed in Table 1. Non-pathogen bacteria made a group (Bacillus spp. group, Escherichia spp. group, Staphylococcus spp. group, and Listeria spp. group) and carried out multiplex PCR in multiple primers. Pathogen bacteria were assayed using multiplex PCR in single and multiple primers.

To determine the detection limit of the PCR, using extracted DNA and cultured cell. Serial dilutions (1 ng/ $\mu \mathrm{L}, 100 \mathrm{pg} / \mu \mathrm{L}, 10 \mathrm{pg} / \mu \mathrm{L}, 1 \mathrm{pg} / \mu \mathrm{L}, 100 \mathrm{fg} / \mu \mathrm{L}, 10 \mathrm{fg} / \mu \mathrm{L}$, and $1 \mathrm{fg} / \mu \mathrm{L}$ ) of each extracted DNA tested using the multiplex PCR. The DNA extraction used a phenol/chloroform method in five pathogen bacteria (Bacillus cereus KCCM 11341, Escherichia coli O157:H7 Lab collection, Staphylococcus aureus ATCC 25923, Salmonella Enteritidis KCCM 12021, and Listeria monocytogenes ATCC 15313). Cultured cell was used to colony PCR with single and multiple primers. The concentration of cultured cells was estimated by $\mathrm{A}_{625}$, reached between 0.080.1, it made the density $10^{8}$ cells $/ \mathrm{mL}$. Serial dilutions $\left(10^{7}-10^{1}\right.$ cells/ $\mathrm{mL}$ ) of each cultured cell tested using the colony PCR.

\section{PCR conditions}

Reactions with DNA as template were carried out in 50 $\mu \mathrm{L}$ volumes containing $10 \mathrm{pmol}$ of each primer, $0.2 \mathrm{mM}$ of each dNTPs, $5 \mu \mathrm{L}$ of $10 \times$ PCR buffer, $30 \mu \mathrm{g}$ of bovine serum albumin (BSA), and Taq DNA polymerase. And reactions with cultured cell as template were carried out in $25 \mu \mathrm{L}$ volumes containing 10 cells $/ \mu \mathrm{L}$ to $10^{3}$ cells $/ \mu \mathrm{L}$ of each cultured cells, $10 \mathrm{pmol}$ of each primers, and 12.5 $\mu \mathrm{L}$ of $2 \times \mathrm{GoTaq}^{\circledR}$ Green Master Mix (Promega, USA).

Thermocycling conditions included an initial denaturation $5 \mathrm{~min}$ at $94^{\circ} \mathrm{C}$, then a denaturation step at $94^{\circ} \mathrm{C}$ for $45 \mathrm{sec}$, annealing at $55^{\circ} \mathrm{C}$ for $45 \mathrm{sec}$, and a $45 \mathrm{sec}$ extension at $72^{\circ} \mathrm{C}$ for total of 40 cycles. The final extension was done at $72^{\circ} \mathrm{C}$ for $10 \mathrm{~min}$. The amplified PCR products were resolved via electrophoresis in a $1 \%$ agarose gel.

\section{Inoculated food}

The commercial low-fatted milk (Namyang Co., Korea) which purchased in a local market, was used as experimental subject (food). The samples to be tested were prepared as follows: $1 \mathrm{~mL}$ of milk was inoculated $10^{4}, 10^{3}$, and $10^{2}$ cells $/ \mathrm{mL}$. Then, $9 \mathrm{~mL}$ of TSB was added into the inoculated milk samples to get the final cell numbers of $10^{3}-10^{1}$ per $\mathrm{mL}$. The samples were incubated at $37^{\circ} \mathrm{C}$ for
$18 \mathrm{~h}$ and were used for PCR assay. Before PCR reaction, cultured cells were washed with peptone water.

\section{Results and Discussion}

The simplex and multiplex PCRs were carried out on DNA extracted by boiling method to verify the specificity of the primers. In the preliminary study (data not shown), primers were not cross-reacted with those of other pathogens and, were designed to target specific genes in the presence of pathogenic bacteria. Target genes were selectively amplified by designed-primers using the NCBI BLAST test results. As a result, it appeared that a product amplified by primers was not confirmed in non-pathogenic bacteria and that these are effective to differentiate the strains. These results with a good specificity were similar to those in other researches that carried out for the simultaneous detection of pathogens in foods using multiplex PCR (Chiang, 2012; Omiccioli, 2009; Yang et al., 2013b).

In this study, the specific primers for L. monocytogenes amplified an expected $611 \mathrm{bp}$ fragment from DNA of $L$. monocytogenes and no amplification was found with $E$. coli $\mathrm{O} 157: \mathrm{H7}$, B. cereus, Salmonella spp., and S. aureus. Similarly, each primer produced specific fragments of 519 bp for Escherichia coli O157:H7, 437 bp for B. cereus,

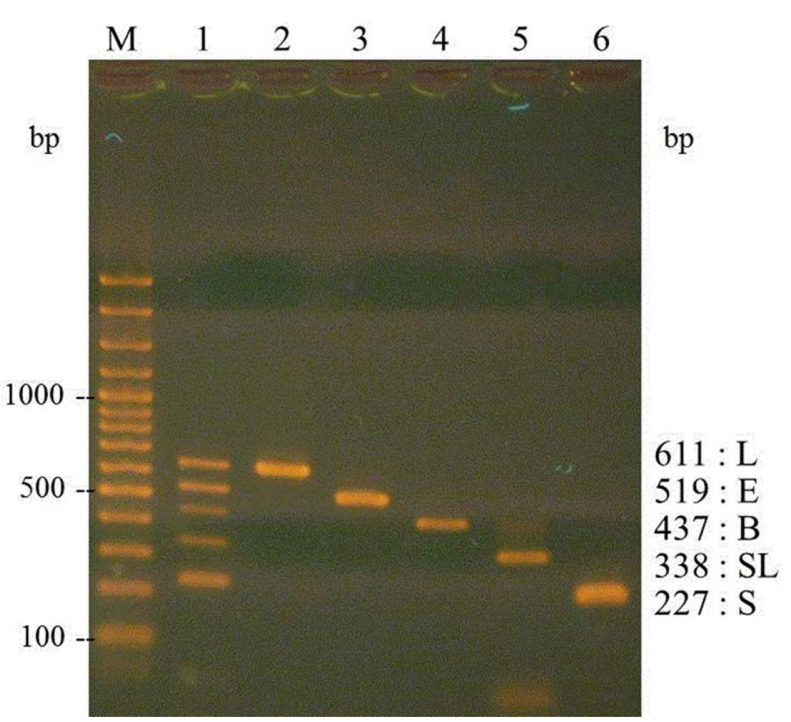

Fig. 1. Specificity of multiplex PCR by multiple primer. The size of the PCR products obtained for Listeria monocytogenes (611 bp), Escherichia coli O157:H7 (519 bp), Bacillus cereus (437 bp), Salmonella Enteritidis (338 bp), and Staphylococcus aureus (227 bp), respectively. Lane M, 100 bp DNA ladder marker; lane 1, multiple DNA; lane 2, Listeria monocytogenes; lane 3, Escherichia coli O157:H7; lane 4, Bacillus cereus; lane 5, Salmonella Enteritidis; lane 6, Staphylococcus aureus. 


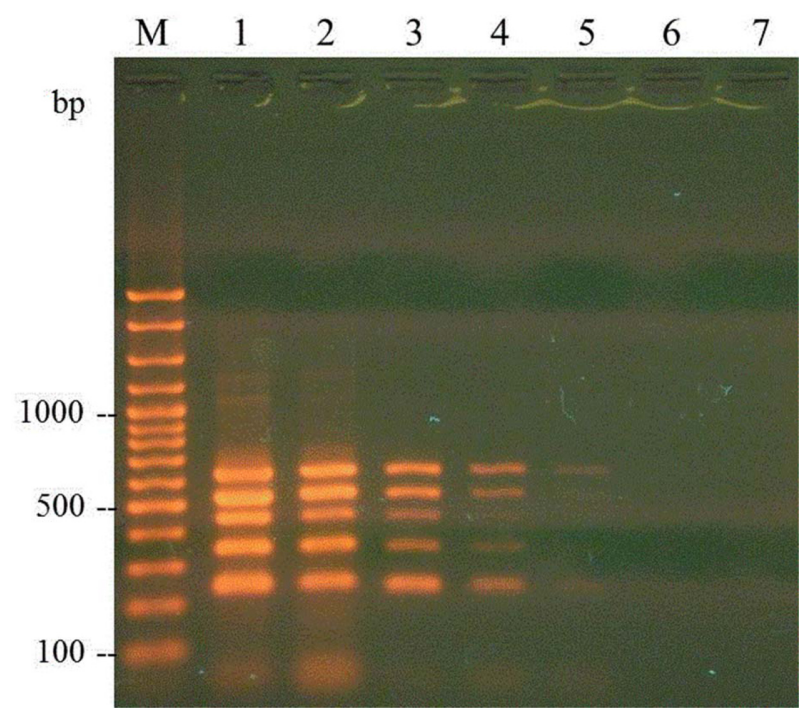

Fig. 2. The detection limits of serially diluted DNA by multiplex PCR assay. Each DNA was included by the density of line 1-7. Lane M, $100 \mathrm{bp}$ DNA ladder marker; lane 1, 1 $\mathrm{ng} / \mu \mathrm{L}$; lane $2,100 \mathrm{pg} / \mu \mathrm{L}$; lane $3,10 \mathrm{pg} / \mu \mathrm{L}$; lane $4,1 \mathrm{pg} /$ $\mu \mathrm{L}$; lane 5, $100 \mathrm{fg} / \mu \mathrm{L}$; lane $6,10 \mathrm{fg} / \mu \mathrm{L}$; lane $7,1 \mathrm{fg} / \mu \mathrm{L}$.

338 bp for Salmonella spp., and 227 bp for S. aureus (Fig. 1). From the results, each primer was applied to identify the five pathogenic strains tested in this study $(B$. cereus KCCM 11341, E. coli O157:H7 Lab collection, $S$. aureus ATCC 25923, $S$. Enteritidis KCCM 12021, and $L$. monocytogenes ATCC 15313).

DNA extracted by the phenol/chloroform method and the genomic DNA extraction kit method showed the enough density to confirm detection limit. In addition, it was found that a purity of DNA in phenol/chloroform method was similar as those of genomic DNA extraction kit method. During the PCR reaction, it have been known that, by adding BSA, Taq DNA polymerase can react more reliably and the reaction can be more sensitive and stable to detect pathogenic bacteria (Hyun et al., 2005; Oikarinen et al., 2009; Strien et al., 2013). According to the results from the multiplex PCR carried out on serial diluted DNA containing $30 \mu \mathrm{g}$ of BSA, it was found that the minimum concentration of template DNA required for the multiplex PCR reaction was approximately $1 \mathrm{pg} /$ $\mu \mathrm{L}$, and that amplification within a lower density than those in a previous study was possible (Yang et al., 2013b). A product amplified was not confirmed with DNA less than $100 \mathrm{fg}$ in detail (Fig. 2).

The sensitivity of the multiplex PCR for simultaneous detection of the tested bacteria was performed using the detection limit as presented in Fig. 3 and 4. The detection limits of pathogenic bacteria in a single primer (Fig. 3) were compared to those of pathogenic bacteria by multiple primers (Fig. 4). In case of the cultured cells using colony PCR without going through the process of DNA extraction, amplification occurs when using only the target of each primer. When using multiple primers, it was less efficient than before, confirmation was possible in all cases except for $B$. cereus and $S$. aureus. The results suggest that this method can be efficient in terms of using multiple primers without significant difference.

Milk is consumed in a variety of patterns, so pay attention to food safety. It has a characteristic to be contaminated in a low density of pathogens. Thus, the situation made by inoculating various concentrations of pathogen bacteria in the milk. Cultured milk samples without extracting genomic DNA was tested by colony PCR using master mix (Packeiser et al., 2013). The results showed that after $18 \mathrm{~h}$ incubation, the multiplex PCR assay was able to correctly identify the presence of the five pathogens at all the different contamination levels and down to the lowest concentration of $10^{2}$ cells $/ \mathrm{mL}$ (Fig. 5). The results for the detection limit within this work were com-
(A)

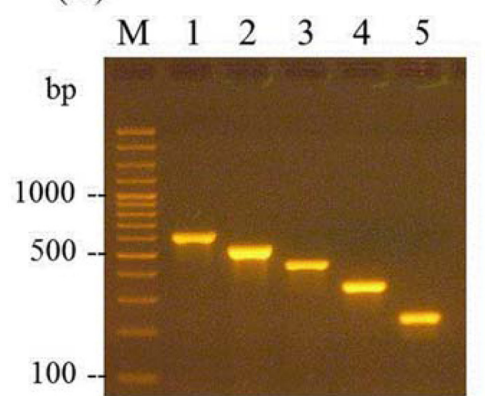

(B)

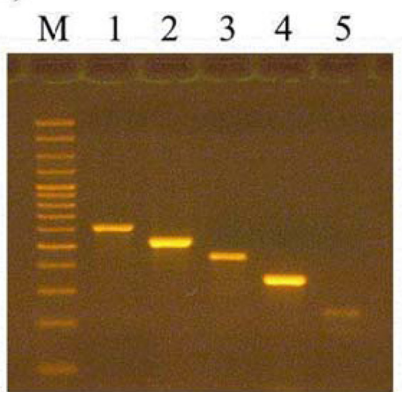

(C)

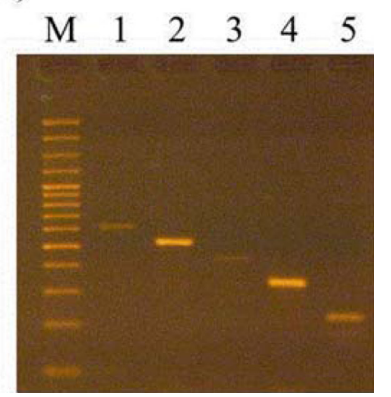

Fig. 3. The detection limits of pathogenic bacteria by single primer. (A) $10^{3}$ cells $/ \mathrm{mL}$; (B) $10^{2}$ cells $/ \mathrm{mL}$; (C) $10^{1}$ cells $/ \mathrm{mL}$. Lane M, 100 bp DNA ladder marker; lane 1, Listeria monocytogenes; lane 2, Escherichia coli O157:H7; lane 3, Bacillus cereus; lane 4, Salmonella Enteritidis; lane 5, Staphylococcus aureus. 
(A)

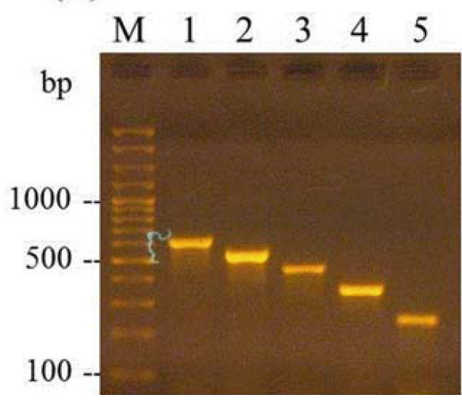

(B)

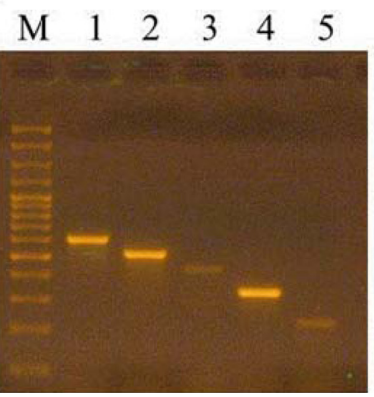

(C)

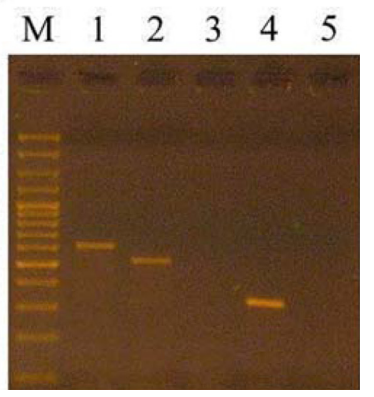

Fig. 4. The detection limits of pathogenic bacteria by multiple primer. (A) $10^{3}$ cells $/ \mathrm{mL}$; (B) $10^{2}$ cells $/ \mathrm{mL}$; (C) $10^{1}$ cells $/ \mathrm{mL}$. Lane M, 100 bp DNA ladder marker; lane 1, Listeria monocytogenes; lane 2, Escherichia coli O157:H7; lane 3, Bacillus cereus; lane 4, Salmonella Enteritidis; lane 5, Staphylococcus aureus.

(A)

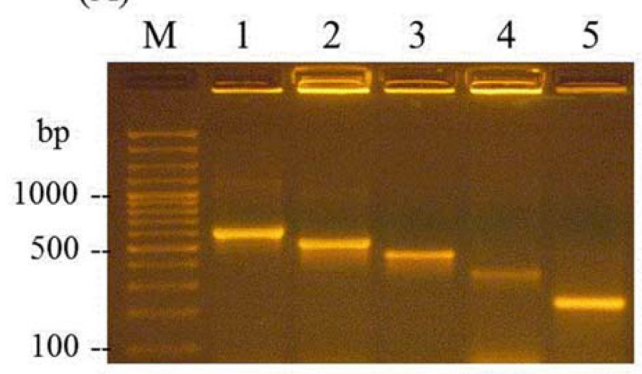

(C)

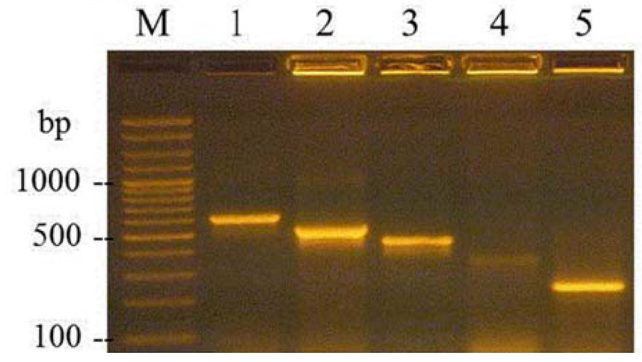

(B)

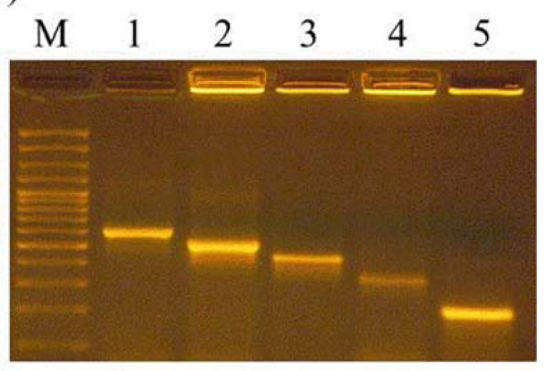

(D)

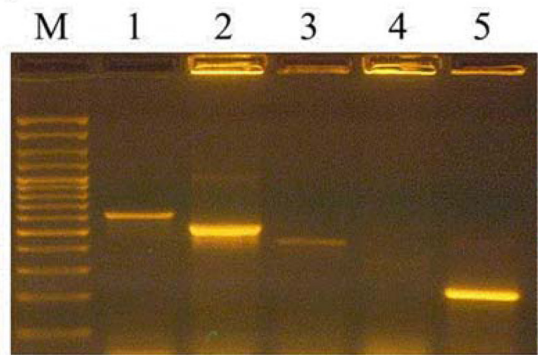

Fig. 5. The detection limits of pathogenic bacteria in milk. (A) $10^{4}$ cells $/ \mathrm{mL}$; (B) $10^{3}$ cells $/ \mathrm{mL}$; (C) $10^{2}$ cells $/ \mathrm{mL}$; (D) $10^{1}$ cells $/ \mathrm{mL}$. Lane M, 100 bp DNA ladder marker; lane 1, Listeria monocytogenes; lane 2, Escherichia coli O157:H7; lane 3, Bacillus cereus; lane 4, Salmonella Enteritidis; lane 5, Staphylococcus aureus.

parable with those of other similar researches by Chiang et al. (2012) and Yang et al. (2013b). And the result of $10^{1}$ cells $/ \mathrm{mL}$ is vague, but can confirm a result amplified all. Therefore, each pathogenic bacterial contamination applied with, all pathogenic bacteria can be detected in the experiment.

In conclusion, primers used in this study were enough to amplify five kinds of pathogenic bacteria at the same time. The experiments on food had acceptable result for multiplex PCR. Therefore, multiplex PCR development in this study may be applied to foods such as dairy products and meat products in a wide range of possibilities.

\section{References}

1. Abd-Elmagid, A., Garrido, P. A., Hunger, R., Lyles, J. L., and Mansfield, M. A., Gugino, B. K., Smith, D. L., Melouk, H. A., and Garzon, C. D. (2013) Discriminatory simplex and multiplex PCR for four species of the genus Sclerotinia. J. Microbiol. Meth. 92, 293-300.

2. Amagliani, G., Brandi, G., Omiccioli, E., Casiere, A., Bruce, I. J., and Magnani, M. (2004) Direct detection of Listeria monocytogenes from milk by magnetic based DNA isolation and PCR. Food Microbiol. 21, 597-603.

3. Bhagwat, A. A. (2003) Simultaneous detection of Escherichia coli O157:H7, Listeria monocytogenes and Salmonella strains by real-time PCR. Int. J. Food Microbiol. 84, 217-224. 
4. Chiang, Y. C., Tsen, H. Y., Chen, H. Y., Chang, Y. H., Lin, C. K., Chen, C. Y., and Pai, W. Y. (2012). Multiplex PCR and a chromogenic DNA macroarray for the detection of Listeria monocytogens, Staphylococcus aureus, Streptococcus agalactiae, Enterobacter sakazakii, Escherichia coli O157:H7, Vibrio parahaemolyticus, Salmonella spp. and Pseudomonas fluorescens in milk and meat samples. J. Microbiol. Meth. 88, 110-116.

5. Cremonesi, P., Luzzana, M., Brasca, M., Morandi, S., Lodi, R., Vimercati, C., Agnellini, D., Caramenti, G., Moroni, P., and Castiglioni, B. (2005) Development of a multiplex PCR assay for the identification of Staphylococcus aureus enterotoxigenic strains isolated from milk and dairy products. Mol. Cell. Probe. 19, 299-305.

6. Germini, A., Masola, A., Carnevali, P., and Marchelli, R. (2009) Simultaneous detection of Escherichia coli O157:H7, Salmonella spp., and Listeria monocytogenes by multiplex PCR. Food Control. 20, 733-738.

7. Hyun, C., Filippich, L. J., and Hughes, I. (2005) The inhibitory effect of pentobarbitone on reverse transcription-PCR. J. Biochem. Biophys. Methods 62, 63-68.

8. Kim, H. W., Kim, J. H., Rhim, S. R., Lee, K. A., Kim, C. J., and Paik, H. D. (2010) A multiplex PCR assay for the detection of food-borne pathogens in meat products. Korean $J$. Food Sci. Ani. Resour. 30, 590-596.

9. Kumar, T. D., Murali, H. S., and Batra, H. V. (2009) Simultaneous detection of pathogenic B. cereus, $S$. aureus and $L$. monocytogenes by multiplex PCR. Indian J. Microbiol. 49, 283-289.

10. Mukhopadhyay, A. and Mukhopadhyay, U. K. (2007) Novel multiplex PCR approaches for the simultaneous detection of human pathogens: Escherichia coli $\mathrm{O} 157: \mathrm{H} 7$ and Listeria monocytogenes. J. Microbiol. Meth. 68, 193-200.

11. Neumann, B., Pospiech, A., and Schairer, H. U. (1992) Rapid isolation of genomic DNA from Gram-negative bacteria. Trends Genet. 8, 332-333.

12. Oikarinen, S., Tauriainen, S., Viskari, H., Simell, O., Knip, M., Virtanen, S., and Hyoty, H. (2009) PCR inhibition in stool samples in relation to age of infants. J. Clin. Virol. 44, 211214.
13. Omiccioli, E., Amagliani, G., Brandi, G., and Bruce, I. J. (2009) Magnani M. Simultaneous direct detection of Salmonella spp., Listeria monocytogenes and Escherichia coli $\mathrm{O} 157$ in milk samples by magnetic extraction and multiplex PCR. $J$. Rapid Meth. Aut. Mic. 17, 195-213.

14. Packeiser, H., Lim, C., Balagurunathan, B., Wu, J., and Zhao, H. (2013) An extremely simple and effective colony PCR procedure for bacteria, yeasts, and microalgae. Appl. Biochem. Biotechnol. 169, 695-700.

15. Pospiech, A. and Neumann, B. (1995) A versatile quick-prep of genomic DNA from Gram-positive bacteria. Trends Genet. 11, 217-218.

16. Settanni L. and Corsetti, A. (2007) The use of multiplex PCR to detect and differentiate food- and beverage-associated microorganisms: a review. J. Microbiol. Meth. 69, 1-22.

17. Stenfors Arnesen, L. P., O'Sullivan, K., and Granum, P. E. (2007) Food poisoning potential of Bacillus cereus strains from Norwegian dairies. Int. J. Food Microbiol. 116, 292-296.

18. Strien, J., Sanft, J., and Mall, G. (2013) Enhancement of PCR Amplification of Moderate GC-Containing and Highly GCRich DNA Sequences. Mol. Biotechnol. 54, 1048-1054.

19. Yang, Q., Zhao, S., Kucerova, Z., Stejskal, V., Opit, G., Qin, M., Cao, Y., Li, F., and Li, Z. (2013a) Validation of the $16 \mathrm{~S}$ rDNA and COI DNA barcoding technique for rapid molecular identification of stored product psocids (Insecta: Psocodea: Liposcelididae). J. Econ. Entomol. 106, 419-425.

20. Yang, Y. J., Xu, F., Xu, H., Aguilar, Z. P., Niu, R. J., Yuan, Y., Sun, J., You, X. Y., Lai, W., Xiong, Y. H., Wan, C. X., and Wei, H. (2013b) Magnetic nano-beads based separation combined with propidium monoazide treatment and multiplex PCR assay or simultaneous detection of viable Salmonella Pyphimurium, Escherichia coli $\mathrm{O} 157: \mathrm{H} 7$ and Listeria monocytogenes in food products. Food Microbiol. 34, 418-424.

21. Yuan, Y., Xu, W., Zhai, Z., Shi, H., Luo, Y., Chen. Z, and Huang, K. (2009) Universal primer-multiplex PCR approach for simultaneous detection of Escherichia coli, Listeria monocytogenes, and Salmonella spp. in food samples. J. Food Sci. 74, 446-452.

(Received 2014.2.14/Revised 2014.6.12/Accepted 2014.7.28) 